\title{
TOWARDS ABOLISHING IMPOSING COMPREHENSIVE SANCTION: SANCTION DAMAGED IRAQI SOCIETY AND FOOD RATION SYSTEM SAVED IT FROM FAMINE
}

\author{
Dr. Mohammed Mahdi Saleh
}

\begin{abstract}
The imposing of sanction regime on Iraq by the Security Council was unique in the history of the United Nation. All sanction resolutions adopted by the Security Council since the establishment of United Nation Organization, had exempted food, medicine and humanitarian commodities from sanction regime except in Iraqi case where total blockade was imposed. All commodities including food and medicine were prevented from entering into Iraqi territories. Consequently, all exported commodities which are basically oil and oil product, and which generates $95 \%$ of total foreign currency were prohibited. Around $\$ 150$ billion of the oil revenue meant for the Iraqi people were deprived during the sanction. Thus, international trade was affected by this value. Food Ration System which was adopted science the beginning of imposing sanction in $6^{\text {th }}$ of August 1990 proved successful in saving Iraqi people from famine. High death rate and malnutrition prevailed during thirteen years of sever sanction due to the lack of sufficient food, medicine, pure water supply, electricity, equitable sanitation etc. Increase in unemployment, decline in the educational system, dismantle of the society and a crippling of the economy of Iraq, are all the consequences of imposing sanction. Even when sanction was lifted after 2003 war erupted against Iraq, society is still suffering from the impact of comprehensive sanction imposed on them. The main victims were Iraqi people. The aim of this paper is to call on the international community to abolish the imposing of sanction regime on countries because the socioeconomic cost is devastating for people.
\end{abstract} famine

Keywords: imposing, Sanction, Iraqi society, food ration,

\section{Introduction}

Two decades (1970-1990) before the imposition of sanction, Iraq has witnessed rapid and vast socio-economic development processes. The revenue of oil exceeded \$20 billion for some years after the nationalization of Oil in 1972. After five years, National Development Plans were adopted. However, the industrial sector, agricultural sector, transport sector, education, health, pure water supply, and sanitation systems were developed rapidly.

Specifically, imported skilled and non-skilled employment reached 3 million in 1970 due to the shortage of employment created by the vast development process. Therefore, Iraq became one of the countries which have the best health and education system in the region. Imported food was available to meet the need of people and industry in highly subsidized prices. Electricity and pure water supply covered both urban and most rural areas.

United Nation report (Annex II of S/1999/356) summarized the situation of Iraq before imposing comprehensive sanction on the $6^{\text {th }}$ of August 1990 as follows: "
1- Iraqi's social and economic indicators were generally above the regional and developing country averages. GDP in 1989 stood at \$75.5 billion for population of 18.3 million. GDP growth had an average of $10.4 \%$ from 1974 to 1980 . By 1988, GDP per capita totaled 3510 US dollars. The concerted push for economic growth from the midseventies onward had benefited the country's infrastructure... Even during 1980-88 war with Iran, the road and railway network were expanded.

2- In 1990, there were 126 power station units capable of generating $8.903 \mathrm{mw}$. This is with oil accounting for $60 \%$ of the country's GDP and $95 \%$ of foreign currency erring. Iraqi's economy was heavily dependent on the external sector and sensitive to oil price fluctuations. Such dependence on oil export would subsequently expose Iraq to high degree of vulnerability to sanction. In the early 1980 s, Iraq had been producing as much as 3.5 million barrels per day.

3- As highlighted by FAO, at that time Iraq had one of the highest per capita food availability indicators in the region. Dietary energy supply averaged 3120 kilo calories per capita/per day. Due to its relative prosperity, Iraq had the capacity to import large quantities of food, which met up to third of its requirements at an average estimated cost of 2.5 billion US dollars a year. Although in poor production years, the food bill could rise to 3 billion.

4- According to WHO, prior to 1991 health care reached approximately $97 \%$ of the urban population and $78 \%$ of rural residents. A major reduction of young child mortality took place from 1960 to 1990 , with mortality rate at 65 per 1000 live births in 1989 (1991 Human Development Report average for developing countries was 76 per 1000 live births). UNICEF indicates that a national welfare system was in place to assist orphans or children with disabilities and support the poorest families.

5- As described by UNICEF, the Government of Iraq made sizable investment in the education sector from mid-1970 until 1990. By 1989, the combined primary and secondary enrolment ratio stood at $75 \%$ slightly above the average for all developing countries at $70 \%$. Illiteracy had been reduced to 20 by 1987; and education accounted for over $5 \%$ of the state budget in 1989, above the developing country average of $3.8 \%$. 
6- WHO estimates that $90 \%$ of the population had access to an abundant collection and sanitary disposal."[1]

\section{Imposing Comprehensive Sanction}

Security Council adopted resolution 661 on the $6^{\text {th }}$ of August through which full and comprehensive sanction were imposed on Iraq to force it to withdraw from Kuwait. Paragraph 3-a prevented all countries to import from Iraq any commodity basically oil and oil products which generate more than $95 \%$ of total foreign currency. Paragraph 3-b prevented all countries to export any commodity to Iraq including $85 \%$ of the food needs which Iraq imports. Paragraph 4 prevented all countries to make available funds or financing to Iraq and froze all Iraqi assets abroad. Accordingly, all procured commodities by public and private sectors before sanction were prevented from entering into the Iraqi territories. Thus, they were returned back to their origin or were confiscated.

Iraq became under complete siege except for Jordan which is the only country that did not adopt sanction regime against Iraq. Additionally, Iraq had small partner trade with Turkey and Dubai (UAE). However, the immediate impact of sanction on inhabitants is hunger. The Iraqi food reserve only met the needs of the market for four months. As a result, this brought about famine in Iraq.

\section{Food Ration System}

Taking into consideration the above mentioned constraints, I as a minister of trade developed and adopted Food Ration System through which the whole food reserve were restricted and regulated towards the main objective of preventing famine from taking place. Food ration system covered all Iraqis and foreigners residing in Iraq. The food ration basket contains item of live saving (wheat flower, rice, pulses, cooking oil, sugar, and tea), soap, and detergent for cleaning body and cloth for the inhabitant for the purpose of preventing epidemic. The price of food basket fixed during thirteen years of sanction was $\$ 0.12$ per person per months. After seven years of sever sanction, Iraq and the United Nations started adopting oil-for-food program through which Food Ration System was adopted by U. N. as the only model of food distribution. Food Ration System has proved to be successful in saving Iraqis from famine. [2]

Figure (1) shows the sharp decline in oil revenue during 1990-1996, and it slightly increased during oil-for-food program from 1997-2003. However, it was still below 1989. Calories have proven to have significant correlation with oil revenue as shown in the same table. Iraqi people were deprived about $\$ 150$ billion equal of oil revenue during sanction." Lost income and productivity for period from 1990 to 1995 was estimated at \$265.3 billion". [3]

United Nations considered Iraqi food ration system as the largest and most efficient food distribution of its kind in the world as mentioned in Washington post [4]. Security Council called to keep the system running in its resolution 1742 which was adopted nine days after military operation started against Iraq in March 2003.
Figure (1): oil revenue, calories, and population during sanction
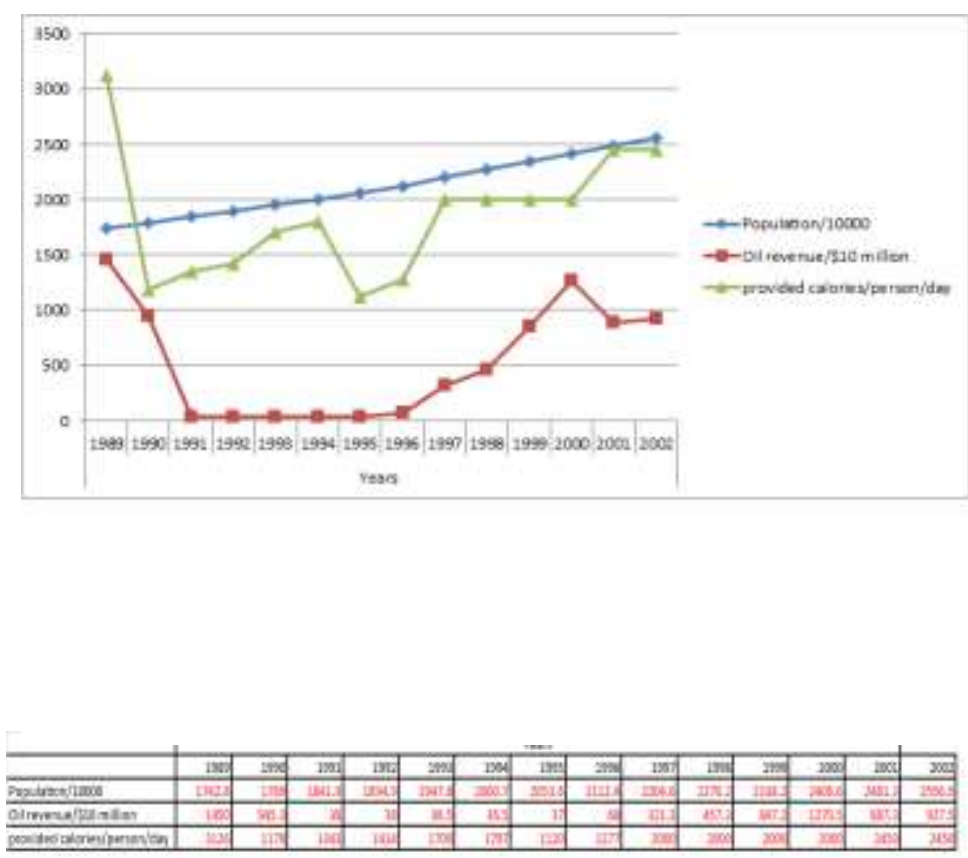

*: after detecting $33 \%$ for compensation and UN expenses.

Despite the successful achievement of avoiding famine to takes place, all other aspects of socio-economic life of the Iraqi people were severely damaged as the consequence of continuation of sanction for thirteen years and the impact of large scale damaged of infrastructure caused by the 1991 war.

\section{The Impact of Sanction and Gulf War}

United Nation summarized the impact of sanction and gulf war on the socio-economic aspects of Iraq as follows:"

1- After the Gulf War and under the effect of sanction, it was estimated that Iraq's GDP may have fallen by nearly two-third in 1991 , owing to an $85 \%$ decline in oil production and the devastation of the industrial and service sectors of the economy. Also, per capita income fell from 3416 US dollars to 450 US dollars in 1995.

2- The maternal mortality rate increased from $50 / 100000$ live births in 1989 to $117 / 100000$ in 1997.

3- The dietary energy supply had fallen from 3120 to 1093 kilo calories per capita/day in 1994-95. The 
prevalence of malnutrition in Iraqi children under five almost doubled from 1991 to 1996 (from 12\% to $23 \%$ ).

4- In addition to the scarcity of resources, malnutrition problems also stem from the massive deterioration in basic infrastructure, in particular in the watersupply and waste disposal system. The WFP estimates that access to potable water is currently $50 \%$ of the 1990 level in urban areas, and only $33 \%$ in rural areas.

5- Increase in juvenile delinquency, begging, anxiety about the future and lack of motivation, a rising sense of isolation bred by absence of contact with the outside world, the development of parallel economy replete with profiteering and criminality, cultural and scientific impoverishment, and disruption of family life. WHO points out that the number of mental health patients attending health facilities rose by $157 \%$ from 1990 to 1998 . UNICEF spoke of a whole generation of Iraqi who are growing up disconnected from the rest of the world... the deterioration in Iraq's cultural life and institution was also noted.

Joy Gordon, an American writer, in her new book titled "THE INVISIBLE WAR" about the impact of sanction imposed on Iraq stated: "What I want to explore now is the question of how human catastrophe of this magnitude came about: what the policies and practices here that caused hundreds of thousands of deaths; decimated the health of several million children; destroyed the whole economy; made a shamble nation's education and health care systems; reduced sophisticated country, in which much of the population lived as the middle class in the First World, to status of Fourth World countries - the poorest of the poor, such as Rwanda, Somalia, Haiti; in a society notable for its scientists, engineers, and doctors, established an economy dominated by baggers, criminals, and black marketers. These things do not come from blocking shipments of glue and laundry detergent, or even from building palaces. They are the result of measures that compromised the economy as a whole by broadly restricting imports in a society that was heavily dependent on imports; by restricting or undermining oil sale in an economy that was heavily dependent on oil sales for its gross domestic product (GDP ); and by undermining the infrastructure-electricity production, telecommunications, transport, and water and sewage treatment-in an advanced industrialized society that was highly dependent on modern infrastructure"[5].

\section{Conclusion}

\section{People are the Only Victim of Sanction}

The above two independent sources: the U.N. and the American famous writer specialized in sanction, gave clear picture about how sanction has turned modern society to poor ones. An envoy from U.N. interviewed me about sanction in summer of 2005 . His main question was what do you think about sanction? My answer briefly was: "Don't punish people of any country by imposing sanction in order to change its political system".

Sanction failed to force Iraq to withdraw from Kuwait as it was the object of Security Council resolution 661. It failed to force Iraqi people to topple their political regime under its hardship. This is the real object of keeping sanction going on for thirteen years, not for dismantling Iraqi mass distraction weapons which the invasion of Iraq in 2003 proved to be clean from these weapons. The only victim of imposing sanction is people. International community and Security Council are called to abandon imposing comprehensive sanction in the future, whatever the objective is aimed to achieve.

\section{References}

[1] United Nation Report, Annex II, S/1999/356, 30 March 1999.

[2] Saleh, Mohammed Mahdi, Food Ration System Prevented Eminent Famine in Iraq During 1990-2003 Sanction, British Journal of Humanities and Social Science,Vol. 13 (2) July 2015.

[3] Gordon, Joy, Invisible War, Harvard University Press, 2010, page 91.

[4] Chandrasekaran, Rajiv, (Feb.3, 2003), Washington Post Foreign Service, Page AOI.

[5] Gordon, Joy, Ibid. page, 87

About Author

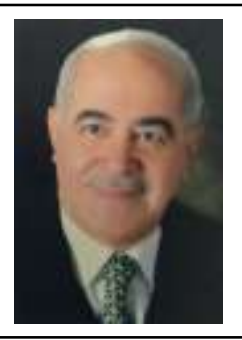

Dr. Mohammed Mahdi Saleh is a PhD holder from Manchester University.

He is a Full-time Postgraduate Lecturer at the Department of International Development, Prince Al- Hussein Bin Abdulla II School of International Studies, Jordan University. 